\title{
Decolorizing Methyl Orange by Fe-Electrocoagulation Process - A Mechanistic Insight
}

\author{
Sara Irki ${ }^{1}$, Djamel Ghernaout ${ }^{1,2, *}$, Mohamed Wahib Naceur ${ }^{1}$, Abdulaziz Alghamdi $^{3}$, \\ Mohamed Aichouni ${ }^{4}$ \\ ${ }^{1}$ Chemical Engineering Department, Faculty of Engineering, University of Blida, Blida, Algeria \\ ${ }^{2}$ Chemical Engineering Department, College of Engineering, University of Ha'il, Ha'il, Saudi Arabia \\ ${ }^{3}$ Mecanical Engineering Department, College of Engineering, University of Ha'il, Ha'il, Saudi Arabia \\ ${ }^{4}$ Industrial Engineering Department, College of Engineering, University of Ha'il, Ha'il, Saudi Arabia
}

\author{
Email address: \\ djamel_andalus@hotmail.com (D.Ghernaout) \\ ${ }^{*}$ Corresponding author
}

\section{To cite this article:}

Sara Irki, Djamel Ghernaout, Mohamed Wahib Naceur, Abdulaziz Alghamdi, Mohamed Aichouni. Decolorizing Methyl Orange by Fe-Electrocoagulation Process - A Mechanistic Insight. International Journal of Environmental Chemistry. Vol. 2, No. 1, 2018, pp. 18-28. doi: $10.11648 /$ j.ijec. 20180201.14

Received: August 9, 2018; Accepted: August 20, 2018; Published: September 13, 2018

\begin{abstract}
The aim of this work is to study the removal of methyl orange (MO) using electrocoagulation (EC) process. An electrochemical cell consisting of two iron electrodes, with $22.5 \mathrm{~cm}^{2}$ as an active surface, is used. Operating conditions are optimized such as nature and concentration of the supporting electrolyte, current density, $\mathrm{pH}$, inter-electrode distance, $\mathrm{MO}$ concentration, and the connection mode. The decolorization degree obtained after $15 \mathrm{~min}$ of EC reached $83 \%$ at $\mathrm{pH} 7.25$ with a current density of $64 \mathrm{~A} / \mathrm{m}^{2}$. Depending on $\mathrm{pH}$, three EC process mechanisms are suggested and less or more significant removal performances are obtained in these tests. The Scanning Electron Microscopy (SEM) observations show that the flocs formed by the EC process have two distinct morphologies: a lumpy structure and an amorphous structure, formed by particles of various sizes. The Energy Disperses X-ray (EDX) analysis of the surface of the flocs formed by the EC process shows a spectrum with levels of major elements of iron, oxygen and chloride, as well as carbon, sodium and aluminum are detected as minor elements. As proved in terms of MO elimination through this research and due to its several advantageous, EC process would find its convenient place in wastewater treatment technology.
\end{abstract}

Keywords: Electrocoagulation (EC), Methyl Orange (MO), Iron, Decolorization, Scanning Electron Microscopy (SEM), Energy Disperses X-ray (EDX) Analysis, Supporting Electrolyte (SE)

\section{Introduction}

Textile and printing industries are considered as the main polluting sectors because of their elevated leakage bulk of dye-containing polluted water [1-3]. Included in such dyes, azo dyes are the main significant types because they form $\sim 50-70 \%$ of the world dye production $[4,5]$. Similar types of dye wastewaters are known for their acute color, elevated organic concentration and unvarying chemical configuration because of the presence of azo groups [6]. Furthermore, they are harmful and refractory to biological decay. Consequently, they have generated dangerous impacts to the nature. Therefore, the elimination of dyes during treating of waste effluents is ecologically vital. As a an azo chemical, methyl orange (MO) is frequently employed as a coloring chemical product in numerous cases, like textile, paint, ink, plastic, and cosmetic sectors. The discharge of this coloring chemical into used water definitely generates a serious ecological issue.

Many technologies [7] have been used to treat polluted waters holding dye chemicals like adsorption, precipitation, chemical degradation, photodegradation, biodegradation and chemical coagulation [8-11]. If conventional coagulation [12-17] is employed to deal with used water containing dye, more pollution may be formed by the chemical products injected at an elevated dose $[18,19]$. The adsorption technique remains one of the efficient processes employed to eliminate dyes from wastewaters. Activated carbon is largely employed adsorbent for dye elimination; however, it remains highly 
costly. Photooxidation using $\mathrm{UV} / \mathrm{H}_{2} \mathrm{O}_{2}$ or $\mathrm{UV} / \mathrm{TiO}_{2}$ and Fenton oxidation need more chemical products [4], and consequently form more pollution [20]. Biological processes are usually economical and easy to use and are at the present day employed to eliminate organic products and color from dyed and textile polluted water. Nevertheless, biological processes are less performant due to the dyes poisoning that constitutes a restraining impact on the bacterial growth. Moreover, such colored used waters cannot be easily decomposed using biological methods, since the constitutions of most commercial dye chemicals are usually too complicated and several dyes are non-biodegradable because of their chemical nature, molecular size, which conducts to sludge bulking.

Electrochemical technique is more efficient for dye elimination [4]. As an electrochemical technique, electrocoagulation (EC) was suggested to prevail over the disadvantages of classical decolorization methods [21-24]. EC is an interesting option for dealing with textile dyes [25]. EC presents an easy, efficient and inexpensive technique for the depollution of used water without any demand for more chemical products, and therefore additional pollution [26, 27]. It as well diminishes the sludge quantity, which requires being removed [28]. EC concerns a technique in which flocs of metallic hydroxides are formed by electrochemical dissolution of sacrificial anodes within the effluent to be treated [29-31]. As sacrificial anodes, iron becomes more generally used than aluminum due to its toxicity [32-35]. The organic chemical in dye-carrying polluted water is coagulated by iron (II)/(III) and iron hydrates or hydroxides formed from the iron anode [36-39].

In a general manner, organic compounds and bacteria obtain their surface charges as a consequence of the ionization of the amino and carboxyl groups as illustrated below [20, 34]:

$$
\begin{array}{r}
R-\mathrm{NH}_{3}{ }^{+} \rightarrow R-\mathrm{NH}_{2}+\mathrm{H}^{+} \\
R-\mathrm{COOH} \rightarrow R-\mathrm{COO}^{-}+\mathrm{H}^{+}
\end{array}
$$

The ensuing charge on the surface of such particles depends on $\mathrm{pH}$. At elevated $\mathrm{pH}$ values or low hydrogen ion contents, Reactions (1) and (2) shift to the right and the colloidal particle becomes negatively charged. At a low $\mathrm{pH}$, Reactions (1) and (2) shift to the left, the carboxyl group is not ionized, and the particle is positively charged because of the ionized amino group. When $\mathrm{pH}$ is at the isoelectric point, the particle is neutral, i.e., neither negatively nor positively charged. Proteinaceous material, carrying different configurations of both amino and carboxyl groups, are frequently negatively charged at $\mathrm{pH}$ values above 4 [40].

The electrolytic dissolution of the iron anode generates $\mathrm{Fe}^{3+}$ ions. As a function of $\mathrm{pH}$, the main reactions occurring in the anodic compartment are listed in Table 1 in the forms of three mechanisms, and the predominance-zone diagrams for $\mathrm{Fe}(\mathrm{II})$ and $\mathrm{Fe}(\mathrm{III})$ chemical species in aqueous solution are shown in Figure 1.

\begin{tabular}{|c|c|}
\hline \multicolumn{2}{|c|}{ Fe mechanisms } \\
\hline Mechanism & Description \\
\hline \multirow{10}{*}{$\begin{array}{l}\text { Mechanism } 1 \\
(\mathrm{pH} 2)\end{array}$} & Anode: \\
\hline & $2 \mathrm{Fe}_{(\mathrm{s})}-4 \mathrm{e}^{-} \rightarrow 2 \mathrm{Fe}^{2+}{ }_{(\mathrm{aq})}\left(E^{\circ}=+0.447 \mathrm{~V}\right)$ \\
\hline & $2 \mathrm{H}_{2} \mathrm{O}_{(\mathrm{l})}-4 \mathrm{e}^{-} \rightarrow \mathrm{O}_{2(\mathrm{~g})}+4 \mathrm{H}_{(\mathrm{aq})}^{+}\left(E^{\circ}=-1.229 \mathrm{~V}\right)$ \\
\hline & Solution: \\
\hline & $2 \mathrm{Fe}^{2+}{ }_{(\mathrm{aq})}+4 \mathrm{OH}_{(\mathrm{aq})}^{-} \rightarrow 2 \mathrm{Fe}(\mathrm{OH})_{2(\mathrm{~s})}$ \\
\hline & Cathode: \\
\hline & $8 \mathrm{H}^{+}{ }_{(\mathrm{aq})}+8 \mathrm{e}^{-} \rightarrow 4 \mathrm{H}_{2(\mathrm{~g})}\left(E^{\circ}=0.000 \mathrm{~V}\right)$ \\
\hline & Total: \\
\hline & $2 \mathrm{Fe}_{(\mathrm{s})}+6 \mathrm{H}_{2} \mathrm{O}_{(\mathrm{l})} \rightarrow \mathrm{O}_{2(\mathrm{~g})}+4 \mathrm{H}_{2(\mathrm{~g})}+2 \mathrm{Fe}(\mathrm{OH})_{2(\mathrm{~s})}$ \\
\hline & Anode: \\
\hline \multirow{9}{*}{$\begin{array}{l}\text { Mechanism } 2 \\
(\mathrm{pH} \mathrm{7)}\end{array}$} & $2 \mathrm{Fe}_{(\mathrm{s})}-4 \mathrm{e}^{-} \rightarrow 2 \mathrm{Fe}^{2+}{ }_{\text {(aq) }}\left(E^{\circ}=+0.447 \mathrm{~V}\right)$ \\
\hline & 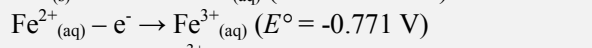 \\
\hline & $\mathrm{Fe}_{(\mathrm{s})}-3 \mathrm{e}^{-} \rightarrow \mathrm{Fe}^{3+}{ }_{(\mathrm{aq})}\left(E^{\circ}=+0.037 \mathrm{~V}\right)$ \\
\hline & Solution: \\
\hline & $\mathrm{Fe}^{2+}{ }_{(\mathrm{aq})}+2 \mathrm{OH}_{(\mathrm{aq})}^{-} \rightarrow \mathrm{Fe}(\mathrm{OH})_{2(\mathrm{~s})}$ \\
\hline & $2 \mathrm{Fe}^{3+}{ }_{(\mathrm{aq})}+6 \mathrm{OH}_{(\mathrm{aq})}^{-} \rightarrow 2 \mathrm{Fe}(\mathrm{OH})_{3(\mathrm{~s})}$ \\
\hline & Cathode: \\
\hline & $8 \mathrm{H}_{2} \mathrm{O}_{(\mathrm{l})}+8 \mathrm{e}^{-} \rightarrow 4 \mathrm{H}_{2(\mathrm{~g})}+8 \mathrm{OH}_{(\mathrm{aq})}^{-}\left(E^{\circ}=-0.828 \mathrm{~V}\right)$ \\
\hline & $3 \mathrm{Fe}_{(\mathrm{s})}+8 \mathrm{H}_{2} \mathrm{O}_{(\mathrm{l})} \rightarrow \mathrm{Fe}(\mathrm{OH})_{2(\mathrm{~s})}+2 \mathrm{Fe}(\mathrm{OH})_{3(\mathrm{~s})}+4 \mathrm{H}_{2(\mathrm{~g})}$ \\
\hline \multirow{8}{*}{$\begin{array}{l}\text { Mechanism } 3 \\
\text { (pH 12) }\end{array}$} & Anode: \\
\hline & $2 \mathrm{Fe}_{(\mathrm{s})}-6 \mathrm{e}^{-} \rightarrow 2 \mathrm{Fe}^{3+}{ }_{(\mathrm{aq})}\left(E^{\circ}=+0.037 \mathrm{~V}\right)$ \\
\hline & Solution: \\
\hline & $2 \mathrm{Fe}^{3+}{ }_{(\mathrm{aq})}+6 \mathrm{OH}_{(\mathrm{aq})}^{-} \rightarrow 2 \mathrm{Fe}(\mathrm{OH})_{3(\mathrm{~s})}$ \\
\hline & Cathode: \\
\hline & $6 \mathrm{H}_{2} \mathrm{O}_{(\mathrm{l})}+6 \mathrm{e}^{-} \rightarrow 3 \mathrm{H}_{2(\mathrm{~g})}+6 \mathrm{OH}_{(\mathrm{aq})}^{-}\left(E^{\circ}=-0.828 \mathrm{~V}\right)$ \\
\hline & Total: \\
\hline & $2 \mathrm{Fe}_{(\mathrm{s})}+6 \mathrm{H}_{2} \mathrm{O}_{(\mathrm{l})} \rightarrow 2 \mathrm{Fe}(\mathrm{OH})_{3(\mathrm{~s})}+3 \mathrm{H}_{2(\mathrm{~g})}$ \\
\hline
\end{tabular}

Table 1. EC mechanisms using Fe electrodes (pH 2, 7 and 12) [20].

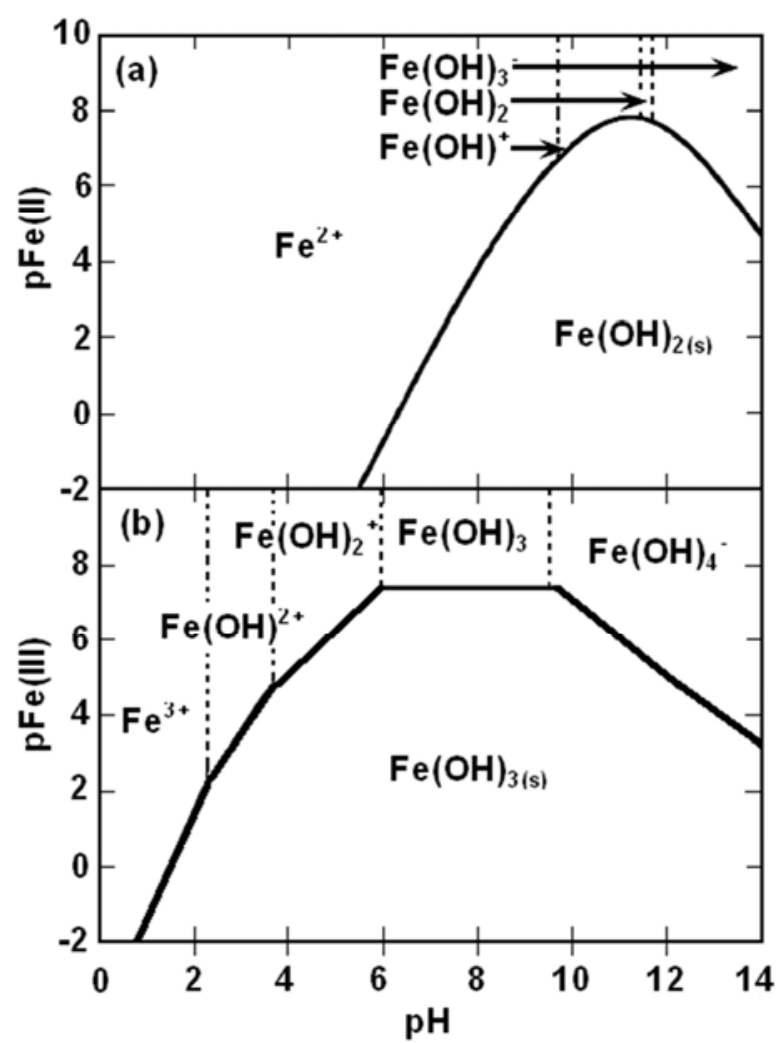

Figure 1. Predominance-zone diagrams for (a) $\mathrm{Fe}(\mathrm{II})$ and (b) $\mathrm{Fe}$ (III) chemical species in aqueous solution. The straight lines represent the solubility equilibrium for insoluble $\mathrm{Fe}(\mathrm{OH})_{2}$ and $\mathrm{Fe}(\mathrm{OH})_{3}$, respectively, and the dotted lines represent the predominance limits between soluble chemical species [41]. 
With good results, EC has been experimented to decolorize MO from used water [42, 43]. With regular volte-face of the electrodes procedure, Pi et al. [43] examined the EC of MO from prepared wastewater. Various working situations like cell voltage, current density $(J)$, and initial content were studied. Upon optimized parameters, a color reduction performance of $97 \%$ was reached [43].

The aim of this work was to evaluate the elevated performance of decolorizing MO from aqueous solution in a relatively extremely short-lived residence upon EC method. In this technique, Fe electrodes were employed as an easy tool upon exercised direct current (DC) and voltage. The influence of the supporting electrolyte (SE), $\mathrm{NaCl}$ concentration $\left(\mathrm{C}_{\mathrm{NaCl}}\right)$, $J$, stirring velocity $(S V), \mathrm{pH}$, inter-electrode distance $(d)$ and MO concentration $\left(C_{M O}\right)$ on the color elimination were examined. Flocs characterization and absorbance tracking were also performed.

\section{Experimental}

\subsection{Experimental Apparatus}

The device employed in EC experiments was made of Plexiglas with the dimensions of $60 \mathrm{~mm} \times 80 \mathrm{~mm}$ (Figure 2). There were two identical Fe electrodes employed, each one with dimensions of $50 \mathrm{~mm} \times 25 \mathrm{~mm} \times 2 \mathrm{~mm}$. The electrodes were connected to a DC power supply (Elektrolyser, type Elyn1) with an ammeter and voltmeter used to control the electric current and the applied voltage during the EC process, respectively. The organic solution in the set-up was stirred on a magnetic stirrer type VWR. Before every each test, the electrode plates were cleaned manually by abrasion with sand paper and by treatment with $15 \% \mathrm{HCl}$ acid followed by washing with distilled water.

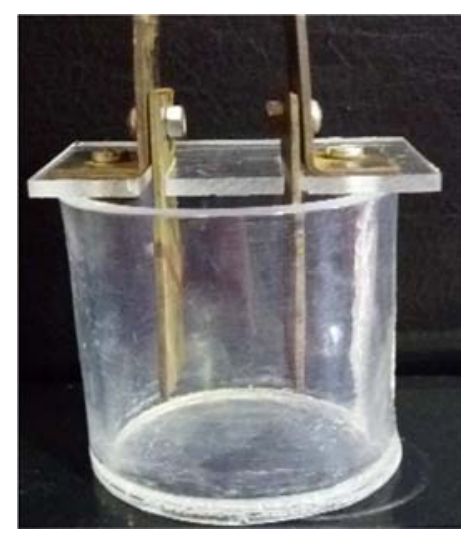

Figure 2. Photo of the apparatus used in the EC tests.

\subsection{Experimental Procedure}

The dye Orange III (abbreviated as methyl orange, MO) is employed for making wastewater solution by dissolving this organic matter in distilled water. The organic solution conductivity levels were set through introducing SE solution to the $200 \mathrm{~mL}$ solution of the synthetic wastewater. The $\mathrm{pH}$ of the examined solutions was determined using Hanna
pH-meter and regulated by adding HCL or $\mathrm{NaOH} 0.05$ N. At the end of the EC tests, all samples were filtered through a $0.45 \mu \mathrm{m}$ pore size syringe filter. The MO concentration $\left(C_{M O}\right)$ was determined employing a UV/Vis spectrophotometer (SHIMADZU UV-1700 pharma Spec) at a wavelength corresponding to the maximum absorbance of the MO (465 $\mathrm{nm})$. The color removal efficiency $R(\%)$ was calculated using Eq. (3):

$$
R(\%)=\left(\frac{A b s_{i}-A b s_{f}}{A b s_{i}}\right) \times 100
$$

where $A b s_{i}$ and $A b s_{f}$ are initial and final absorbance, respectively.

\subsection{Scanning Electron Microscopy (SEM) and Energy Disperses X-ray (EDX) Analysis}

The surface morphology of the formed flocs through EC process was examined under Scanning Electron Microscopy (SEM), using QUANTA 400 from FEI Company. The elemental composition was revealed employing Energy Disperses X-ray (EDX) analysis detector from EDAX system (a division of AMETEK). The flocs samples were separated through decantation, then dried at the ambient air and ground to fine powder.

\section{Results and Discussion}

The impacts of SE concentration $\left(C_{S E}\right), C_{M O}, J$, and $\mathrm{pH}$ of the MO solution were examined in order to determine the optimum operating conditions for the MO maximum removal performance.

\subsection{Effect of the Supporting Electrolyte (SE)}

The SE presence in the solution, in which the EC process is carried out, makes it possible to transport the electroactive species between the solution and the electrodes. Figure 3(a) presents the effect of the SE nature on the MO $R(\%)$ and Figure 3(b) illustrates the influence of $C_{\mathrm{NaCl}}$ on the elimination performance of MO.

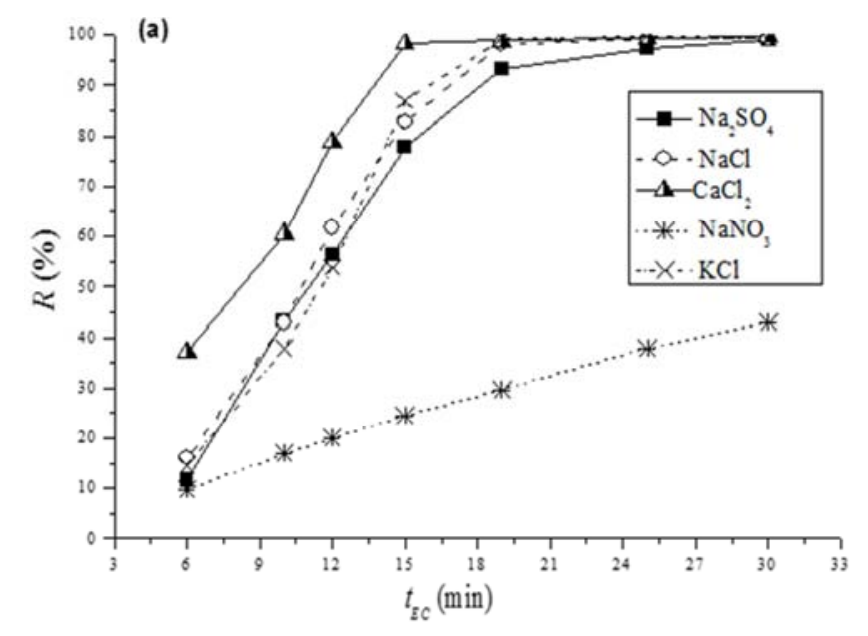




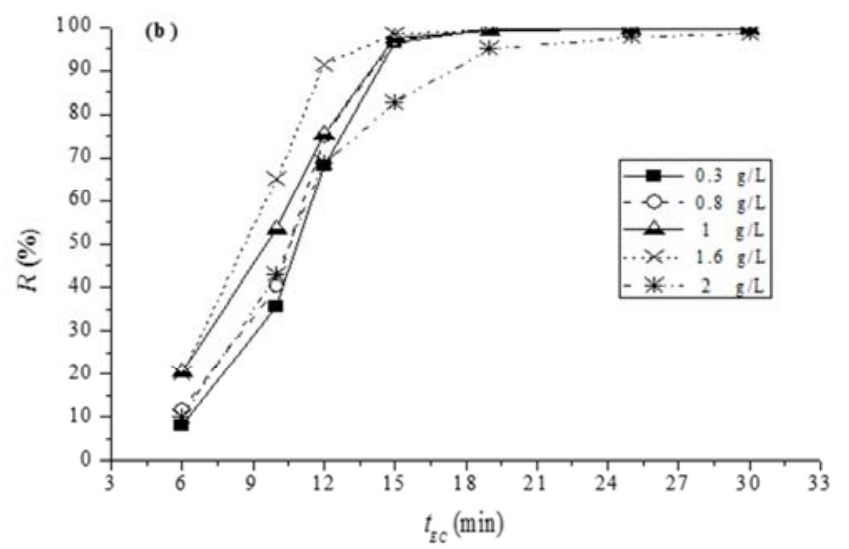

Figure 3. (a) Effect of the SE type on the $M O R(\%)\left(C_{S E}=1 \mathrm{~g} / \mathrm{L}\right)$. (b) Effect of $C_{\mathrm{NaCl}}$ on $R(\%)\left(C_{M O}=15 \mathrm{mg} / \mathrm{L}, J=64 \mathrm{~A} / \mathrm{m}^{2}, d=1 \mathrm{~cm}\right)$.

As shown in Figure 3(a), the obtained results show clearly that the SE nature has a significant influence on the degree of MO decolorization. In decreasing order, $R(\%)$ was: $98.47 \%$, $86.88 \%, 82.34 \%, 77.95 \%$ and $24.44 \%$ for $\mathrm{CaCl}_{2}, \mathrm{KCl}, \mathrm{NaCl}$, $\mathrm{Na}_{2} \mathrm{SO}_{4}$ and $\mathrm{NaNO}_{3}$, respectively (Figure 3(a)). The effects of $\mathrm{CaCl}_{2}, \mathrm{KCl}, \mathrm{NaCl}, \mathrm{Na}_{2} \mathrm{SO}_{4}$ seem to play a significant role in the distribution of the electric species through the solution while $\mathrm{NaNO}_{3}$ appears to be an inhibitor of the dissolution of iron anode [44].

Moreover, the presence of $\mathrm{Ca}^{2+}$ in solution causes the formation of a deposit of scale at the Fe cathode. To avoid this adverse effect, it would be appropriate to use sodium chloride $(\mathrm{NaCl})$ as $\mathrm{SE}$ because the chloride ions can significantly reduce the adverse effects of other anions such as $\mathrm{Ca}^{2+}[45,46]$. This is why $\mathrm{NaCl}$ is widely used as $\mathrm{SE}$ through electrochemical processes applications.

The energy consumption $(E)$ during the EC process is calculated using Eq. (4) [36]:

$$
E(k W h / k g \text { of } M O)=\frac{I \times t_{E C} \times U}{C_{M O} \times V \times 10^{3}}
$$

where $I$ is the current intensity (A), $t_{E C}$ is the EC time (h), $U$ is the cell voltage $(\mathrm{V}), V$ is the volume of solution $\left(\mathrm{m}^{3}\right)$ and $C_{M O}$ is the initial pollutant concentration $\left(\mathrm{kg} / \mathrm{m}^{3}\right)$. Figure $4(\mathrm{a})$ presents the effect of the SE type on both $R(\%)$ and $E\left(C_{S E}=1 \mathrm{~g} / \mathrm{L}\right)$ and Figure 4(b) illustrates the effect of $C_{\mathrm{NaCl}}$ on both $R(\%)$ and $E$.

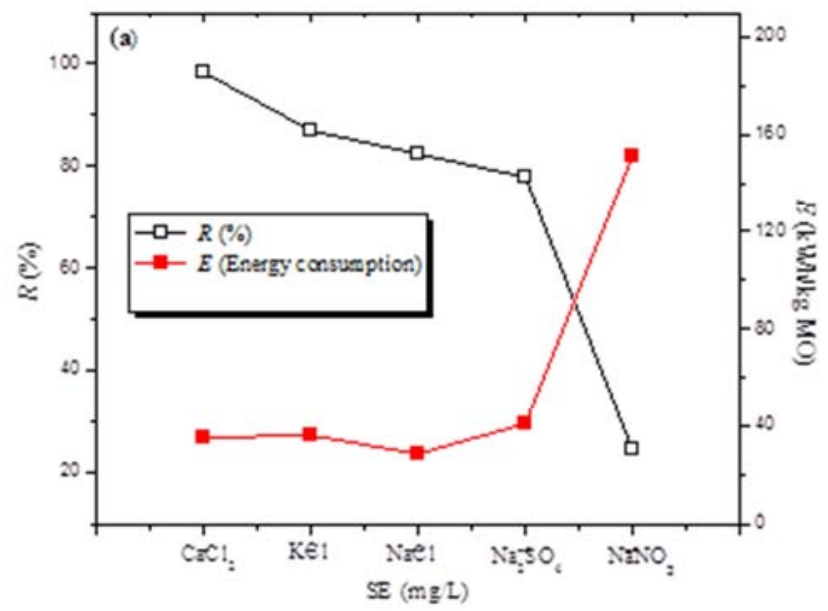

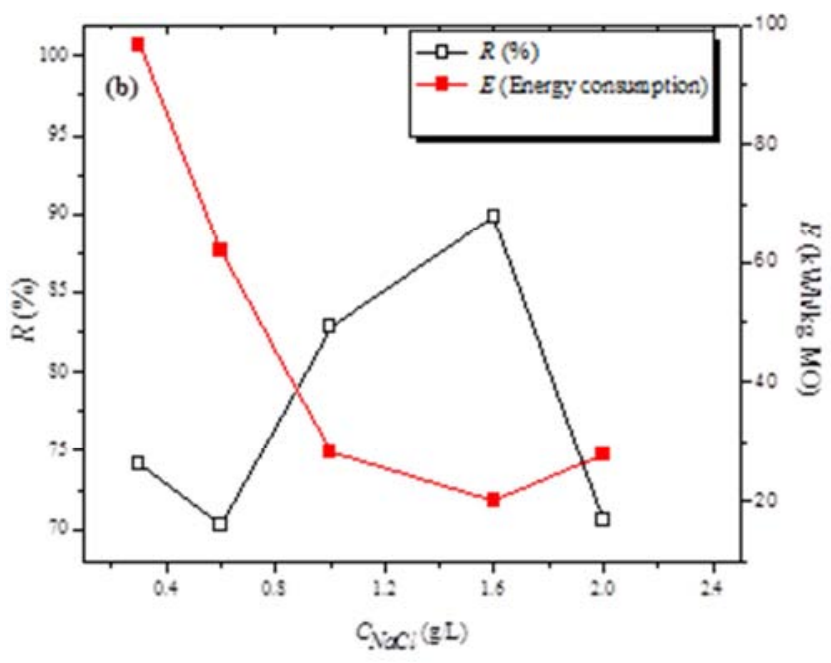

Figure 4. (a) Effect of the SE type on $R(\%)$ and $E\left(C_{S E}=1 \mathrm{~g} / \mathrm{L}\right)$. (b) Effect of $C_{\mathrm{NaCl}}$ on $R(\%)$ and $E\left(C_{M O}=15 \mathrm{mg} / L, J=64 \mathrm{~A} / \mathrm{m}^{2}, d=1 \mathrm{~cm}, t_{E C}=15 \mathrm{~min}\right)$.

As shown in Figure 4(a), $E$ increases considerably with the type of electrolyte used. The energy consumed during the treatment of $\mathrm{MO}$ in the presence of $\mathrm{CaCl}_{2}, \mathrm{KCl}$ and $\mathrm{Na}_{2} \mathrm{SO}_{4}$ is greater than $35 \mathrm{kWh} / \mathrm{kg}$ of MO (Figure 4(a)). Really, the EC process is more meaningful using $\mathrm{NaCl}$ as $\mathrm{SE}$ since the treatment requires about $28.46 \mathrm{kWh} / \mathrm{kg}$ of $\mathrm{MO}$.

\subsection{Effect of $\mathrm{NaCl}$ Concentration}

As seen above, $\mathrm{NaCl}$ is proved to be the best $\mathrm{SE}$ for $\mathrm{MO}$ removal. The concentration of the SE obviously exerts a primary influence on the conductivity of the solution and the voltage applied between the electrodes at a constant $J$ [47].

In order to study the influence of the electric conductivity of the solution on the evolution of the dye removal, $C_{\mathrm{NaCl}}$ was varied from 0.3 to $2 \mathrm{~g} / \mathrm{L}$. As shown in Figure 3(b), the level of MO elimination by EC increases during the first $15 \mathrm{~min}$, up to the plateau of 19 to $30 \mathrm{~min}$, for $C_{\mathrm{NaCl}}=1.6 \mathrm{~g} / \mathrm{L}$. The improvement in the EC effectiveness is obtained after $12 \mathrm{~min}$ with a $69.27 \%$ rate for the EC. After 15 min of EC treatment, the removal rate increases to $89.87 \%$. The result of EC treatment for $15 \mathrm{~min}$ with a dose of $0.3 \mathrm{~g} / \mathrm{L}$ reveals that the elimination performance decreases to $74 \%$ (Figure $3(\mathrm{~b})$ ). An additional salt injection has a negative effect on the EC effectiveness. With a salinity of $1.6 \mathrm{~g} / \mathrm{L}$, it is found that the maximum rate of removal reaches $82.84 \%$ at $15 \mathrm{~min}$. As shown in Figure 4(b), for EC treatment after $15 \mathrm{~min}$, the elimination rate increases from $74 \%$ to $89.87 \%$ and $E$ decreases from 96 to $20 \mathrm{kWh} / \mathrm{kg}$ of $\mathrm{MO}$ for $C_{\mathrm{NaCl}}$ of 0.3 to 1.6 $\mathrm{g} / \mathrm{L}$, respectively.

\subsection{Effect of Current Density (J)}

In the electrochemical processes, the most significant parameters are $J$ and $t_{E C}$. These key parameters make it easy to regulate the rate of reaction in the reactor, which determines the production rate of the coagulant (from anode) and the hydrogen bubbles generation (from cathode). Figure 5(a) presents the effect of $J$ on MO $R(\%)$ and Figure 5(b) illustrates the impact of $J$ on both $R(\%)$ and $E$. 

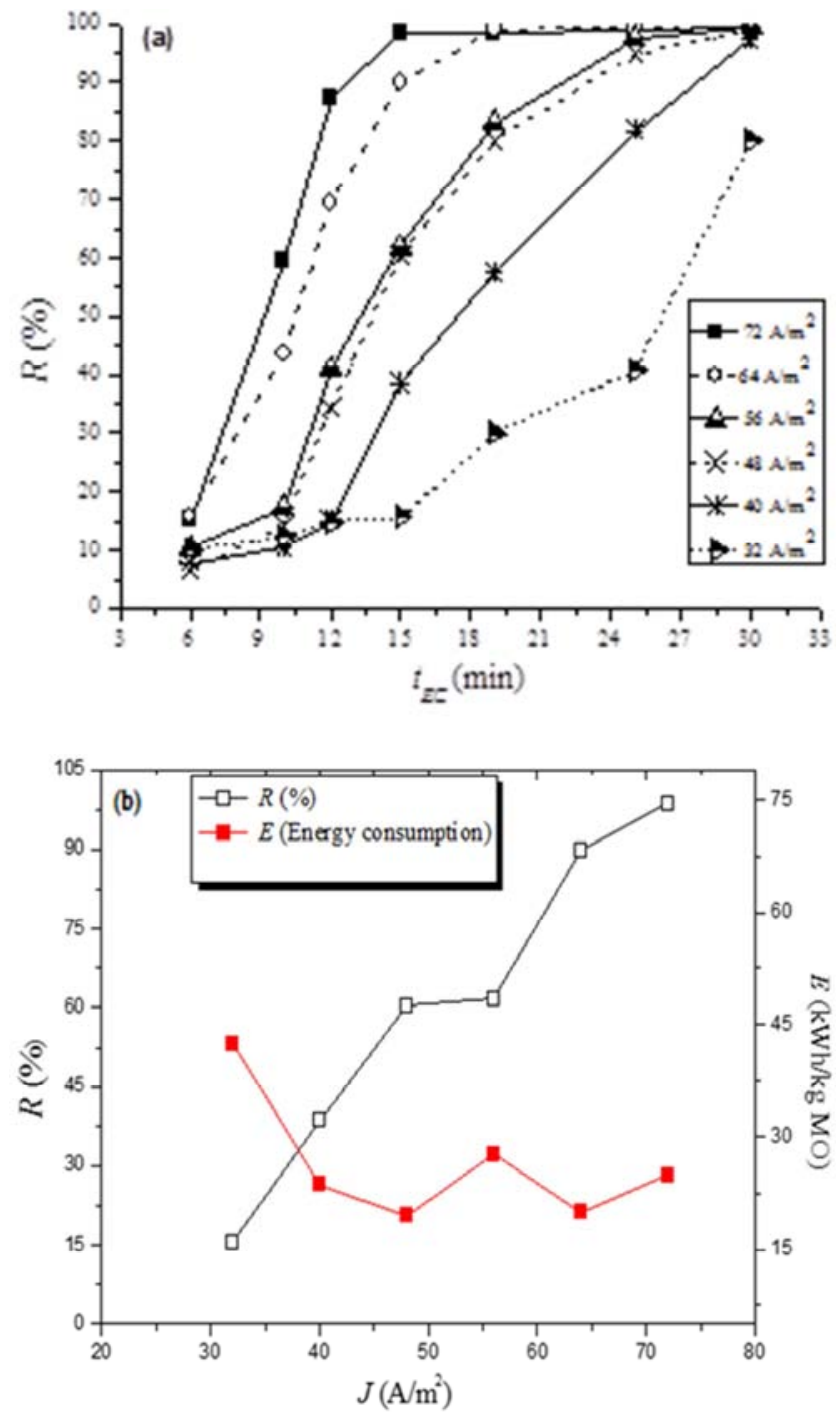

Figure 5. (a) Effect of $J$ on $M O R(\%)$. (b) Effect of $J$ on $R(\%)$ and $E\left(C_{M O}=\right.$ $15 \mathrm{mg} / \mathrm{L}, C_{\mathrm{NaCl}}=1.6 \mathrm{~g} / \mathrm{L}, \mathrm{d}=1 \mathrm{~cm}$ ).

As shown in Figure 5(a), the experimental results achieved by the EC process illustrate that when $J$ decreases from 56 to $32 \mathrm{~A} / \mathrm{m}^{2}$, the removal percentage observed for $15 \min$ is less than $60 \%$. As $J$ increases from 64 to $72 \mathrm{~A} / \mathrm{m}^{2}$, the color elimination is above $80 \%$ (Figure $5(\mathrm{a})$ )).

The results obtained show clearly that the EC efficiency increases as a function of the intensity of the current. Moreover, as $J$ augments $t_{E C}$ decreases leading to an increase in cations release. When $J$ is greater than $64 \mathrm{~A} / \mathrm{m}^{2}$, the dye removal did not change significantly. The judicious choice of the initial conditions (i.e., $t_{E C}$ and $J$ ) will make it easy to limit the excessive release of hydrogen bubbles with the increase of $J$, and $E$ decreases [43, 48, 49].

As shown in Figure 5(b), the energy consumed during EC process is less than $32 \mathrm{kWh} / \mathrm{kg}$ of MO when $J$ decreases from 72 to $40 \mathrm{~A} / \mathrm{m}^{2}$. The energy consumed reaches a maximum value when the density decreases to $32 \mathrm{~A} / \mathrm{m}^{2}$ (Figure 5(b)). In order to satisfy the energy consumption, the treatment should be carried out with $J=64 \mathrm{~A} / \mathrm{m}^{2}$.

\subsection{Effect of Stirring Velocity (SV)}

The main function of agitation is to ensure a good homogenization of the mixture dispersing the coagulant species in the reactor; thus, causing efficient contact between the neutralized molecules and destabilized colloids and the cationic metallic species, which explains a positive effect [50]. The flocculation process allows the aggregation of colloidal particles into flocs $[51,52]$. Any shearing of formed flocs could hinder the removal process, which is the negative effect of increased agitation [50]. To evaluate the effect of $S V$ on the dye removal process, a series of tests with different $S V$, namely: $S V=217 \mathrm{rpm}, 279 \mathrm{rpm}, 450 \mathrm{rpm}, 990 \mathrm{rpm}$ was done. Figure 5(a) presents the effect of number of turns on $R(\%)$ and Figure 5(b) illustrates the effect of number of turns on $R(\%)$ and $E$.
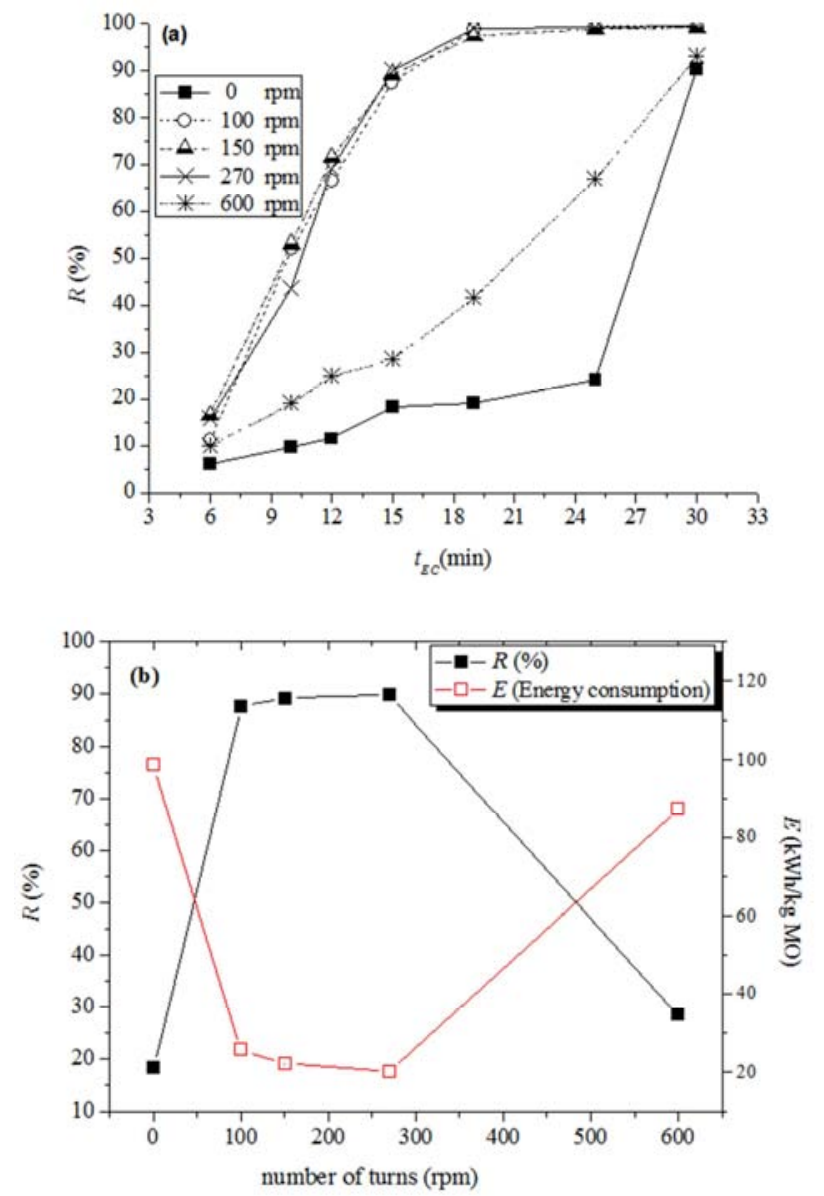

Figure 6. (a) Effect of number of turns on R (\%). (b) Effect of number of turns on $R(\%)$ and $E\left(C_{M O}=15 \mathrm{mg} / \mathrm{L}, C_{\mathrm{NaCl}}=1.6 \mathrm{~g} / \mathrm{L}, \mathrm{J}=64 \mathrm{~A} / \mathrm{m}^{2}, d=1 \mathrm{~cm}\right)$.

A similar evolution of $R(\%)$ is recorded when $S V$ is between 217 and $450 \mathrm{rpm}$. The highest decolorization is $89 \%$; it is reached at $278 \mathrm{rpm}$ after $15 \mathrm{~min}$. It is found that the decolorization efficiency decreases to $28 \%$ when $S V$ is greater than $450 \mathrm{rpm}$, because excessive $S V$ breaks the formed flocs. The non-agitated EC process leads to a decrease in decolorization until 18\% (Figure 6(a)). The increase of the speed of the agitation causes greater $E$ since it reaches up to 87 $\mathrm{kWh} / \mathrm{kg}$ of MO. However, $E$ is close to $20 \mathrm{kWh} / \mathrm{kg}$ of MO in 
the case where the EC process has a speed of $278 \mathrm{rpm}$ (Figure 6 (b)).

\subsection{Effect of $p H$}

The initial $\mathrm{pH}$ is one of the most important parameters that control the process performance of EC [53-55]. Figure 7(a) presents the effect of $\mathrm{pH}$ on $R(\%)$ and Figure 7(b) shows the effect of $\mathrm{pH}$ on both $R(\%)$ and $E$.
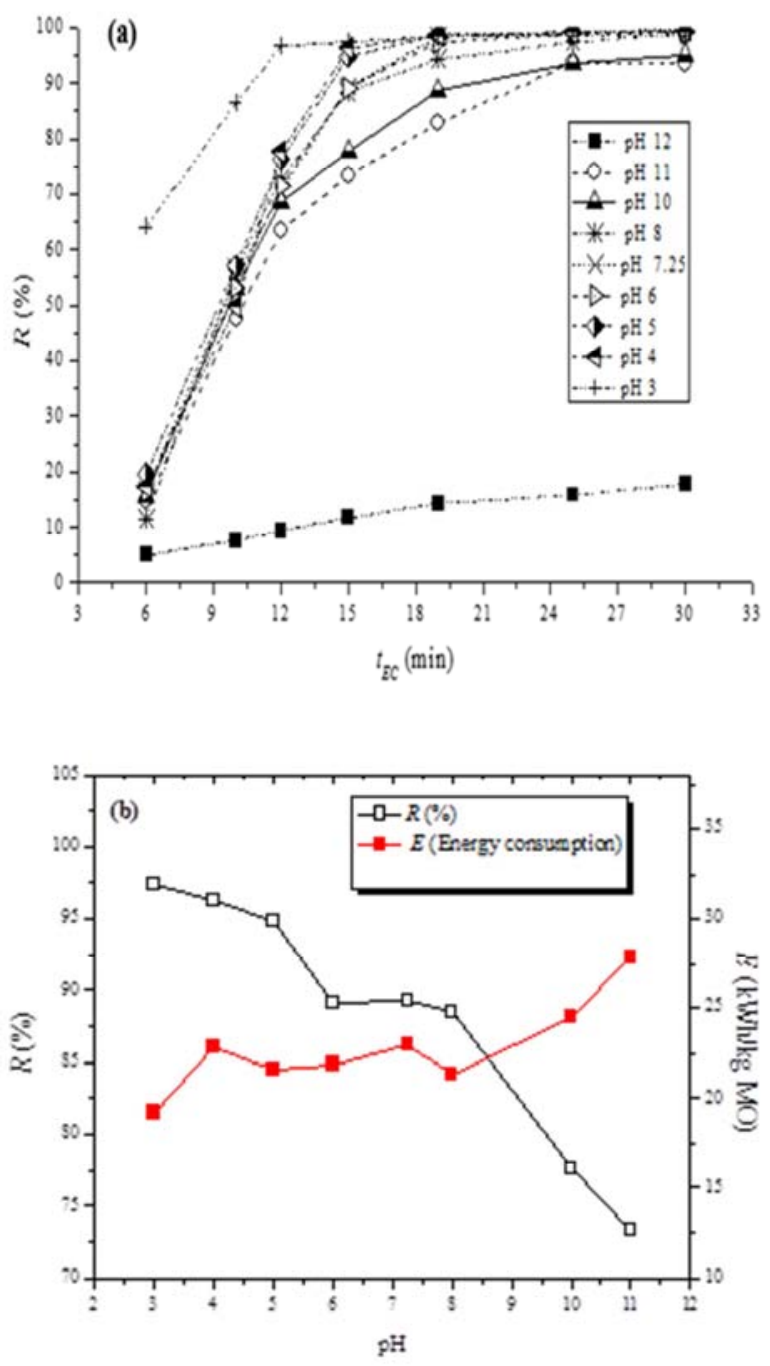

Figure 7. (a) Effect of pH on $R$ (\%). (b) Effect of $p H$ on $R(\%)$ and $E\left(C_{M O}=15\right.$ $\left.\mathrm{mg} / \mathrm{L}, C_{\mathrm{NaCl}}=1.6 \mathrm{~g} / \mathrm{L}, \mathrm{J}=64 \mathrm{~A} / \mathrm{m}^{2}, d=1 \mathrm{~cm}, \mathrm{SV}=270 \mathrm{rpm}\right)$.

A decolorization rate is more rapid and more pronounced after 10 min by the EC treatment at $\mathrm{pH} 3$ in comparison with the other $\mathrm{pH}$ values studied (Figure 7(a)). The discoloration rate by EC treatment increases rapidly and reaches $96 \%$ after $12 \mathrm{~min}$. In the $\mathrm{pH}$ range 4 to 7.25 , the results show that the increase in the decolorization efficiency starts after $12 \mathrm{~min}$ and the recorded rate is higher than $70 \%$ and the maximum rate is reached around $19 \mathrm{~min}$. In the $\mathrm{pH}$ range 9 to 12 , the effectiveness of the treatment decreases and the decolorization rates are below $72 \%$ (Figure 7 (a)). An initial $\mathrm{pH}$ optimum was found between 5 and 8, although a slight difference was noted in the decolorization rate. The value of the decolorization rate is particularly important at $\mathrm{pH} 7.25$ since it is of the order of $70.48 \%$ (see Mechanism 2 (Table 1) and Figure 1(b)). When $\mathrm{pH}$ is low, the protons are reduced to gaseous hydrogen at the cathode and the hydroxide ions cannot be produced [56]. When $\mathrm{pH}$ is low, the iron species $\left(\mathrm{Fe}(\mathrm{OH})_{2}{ }^{+}, \mathrm{Fe}(\mathrm{OH})^{2+}\right)$ formed are advantageous for the coagulation of $\mathrm{MO}[57,58]$. When $\mathrm{pH}$ is between 6 and 8 , the tendency for the formation of iron hydroxide $\left(\mathrm{Fe}(\mathrm{OH})_{3(\mathrm{~s})}\right)$ increases $[57,59]$. An additional increase in $\mathrm{pH}(>8)$ can lead to the formation of the following species: $\mathrm{Fe}(\mathrm{OH})^{+}, \mathrm{Fe}(\mathrm{OH})_{2}, \mathrm{Fe}(\mathrm{OH})_{3}{ }^{-}$and $\mathrm{Fe}(\mathrm{OH})_{4}{ }^{-}$[57] which conduct to the decrease of the decolorization efficiency. In matter of energy, the results show that the EC treatment contributes to the increase of $E$ through the increase of $\mathrm{pH}$ to 11. This increase is of the order of $28 \mathrm{kWh} / \mathrm{kg}$ of MO. The energy consumed at $\mathrm{pH} 7.25$ reaches $23 \mathrm{kWh} / \mathrm{kg}$ of $\mathrm{MO}$ (Figure 7(b)).

\subsection{Effect of the Inter-Electrode Distance (d)}

The distance separating the electrodes $(d)$ is an important parameter involved in the design of the electrochemical cell [60]. Optimizing $d$ contributes to the regulation of the process. To study the influence of $d$ on $R(\%), d$ was varied between 0.8 and $3.1 \mathrm{~cm}$. Figure 8(a) presents the effect of $d$ on $R(\%)$ and Figure 8(b) illustrates the effect of $d$ on $R(\%)$ and $E$.
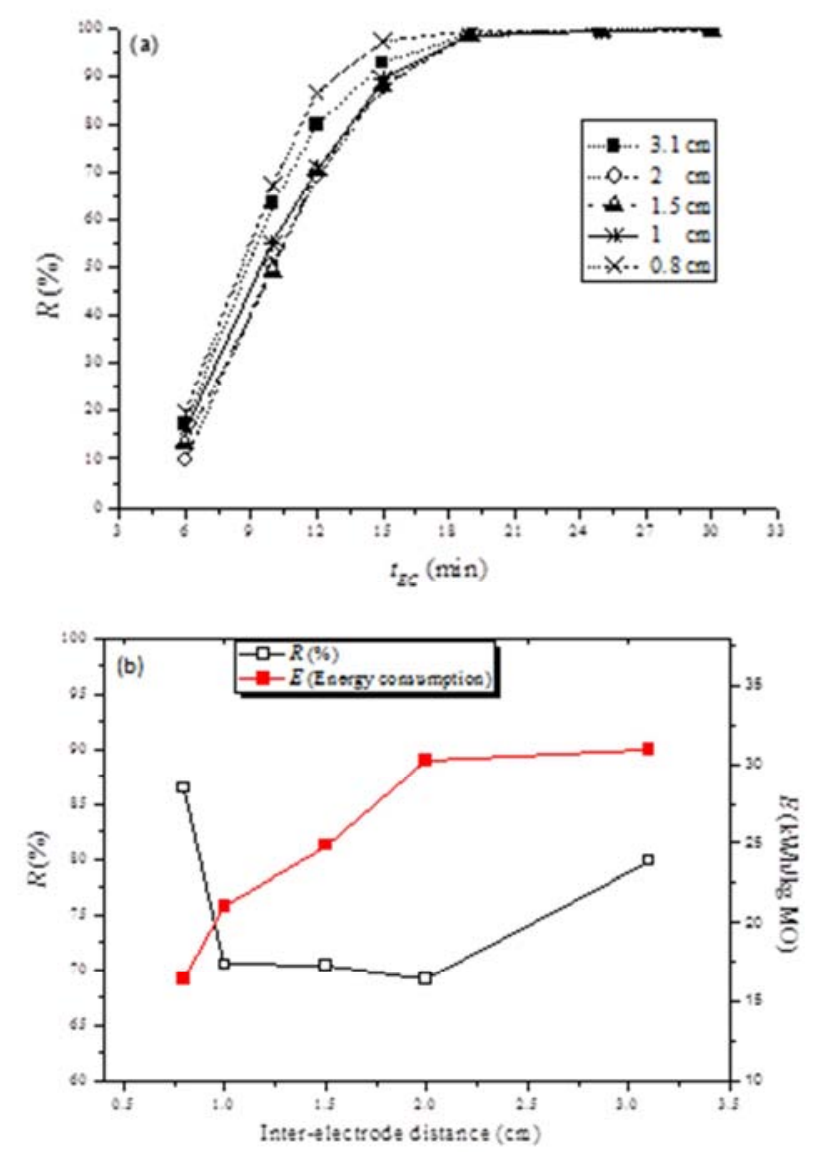

Figure 8. (a) Effect of d on $R(\%)\left(C_{M O}=15 \mathrm{mg} / \mathrm{L}, C_{\mathrm{NaCl}}=1.6 \mathrm{~g} / \mathrm{L}, \mathrm{J}=64 \mathrm{~A} / \mathrm{m}^{2}\right.$, $p H=7.25, S V=270 \mathrm{rpm})$. (b) Effect of $d$ on $R(\%)$ and $E\left(C_{M O}=15 \mathrm{mg} / \mathrm{L}\right.$, $C_{\mathrm{NaCl}}=1.6 \mathrm{~g} / \mathrm{L}, \mathrm{J}=64 \mathrm{~A} / \mathrm{m}^{2}, t_{E C}=12 \mathrm{~min}$ ). 
The results obtained with the EC treatment showed that $R$ (\%) after $12 \mathrm{~min}$ reaches $86 \%$ and $80 \%$ for $d=0.8 \mathrm{~cm}$ and 3.1 $\mathrm{cm}$, respectively (Figure $8(\mathrm{a})$ ). It seems that the removal performance is relatively low for $d$ comprised between 1 and 2 $\mathrm{cm}$. When $d$ is maintained at $2 \mathrm{~cm}$, the EC treatment recorded an efficiency of $70 \%$ for $12 \mathrm{~min}$. Short circuits may occur when $d$ is small [61]. The value of $d=2 \mathrm{~cm}$ is recommended by several authors $[50,61,62]$. EC is relatively more energy consuming at $d=2 \mathrm{~cm}$, representing $30 \mathrm{kWh} / \mathrm{kg}$ of MO; and, when the electrodes are kept at $d$ comprised between 0.8 and 2 $\mathrm{cm}, E$ is less than $24 \mathrm{kWh} / \mathrm{kg}$ of MO (Figure $8(\mathrm{~b})$ ).

\subsection{Effect of the MO Concentration $\left(C_{M O}\right)$}

The initial concentration assessment from 15 to $55 \mathrm{mg} / \mathrm{L}$ was further tested by keeping the other optimized parameters constant. Figure 8(a) presents the effect of $C_{M O}$ on $R(\%)$ and Figure 9(b) illustrates the effect of $C_{M O}$ on $R(\%)$ and $E$.
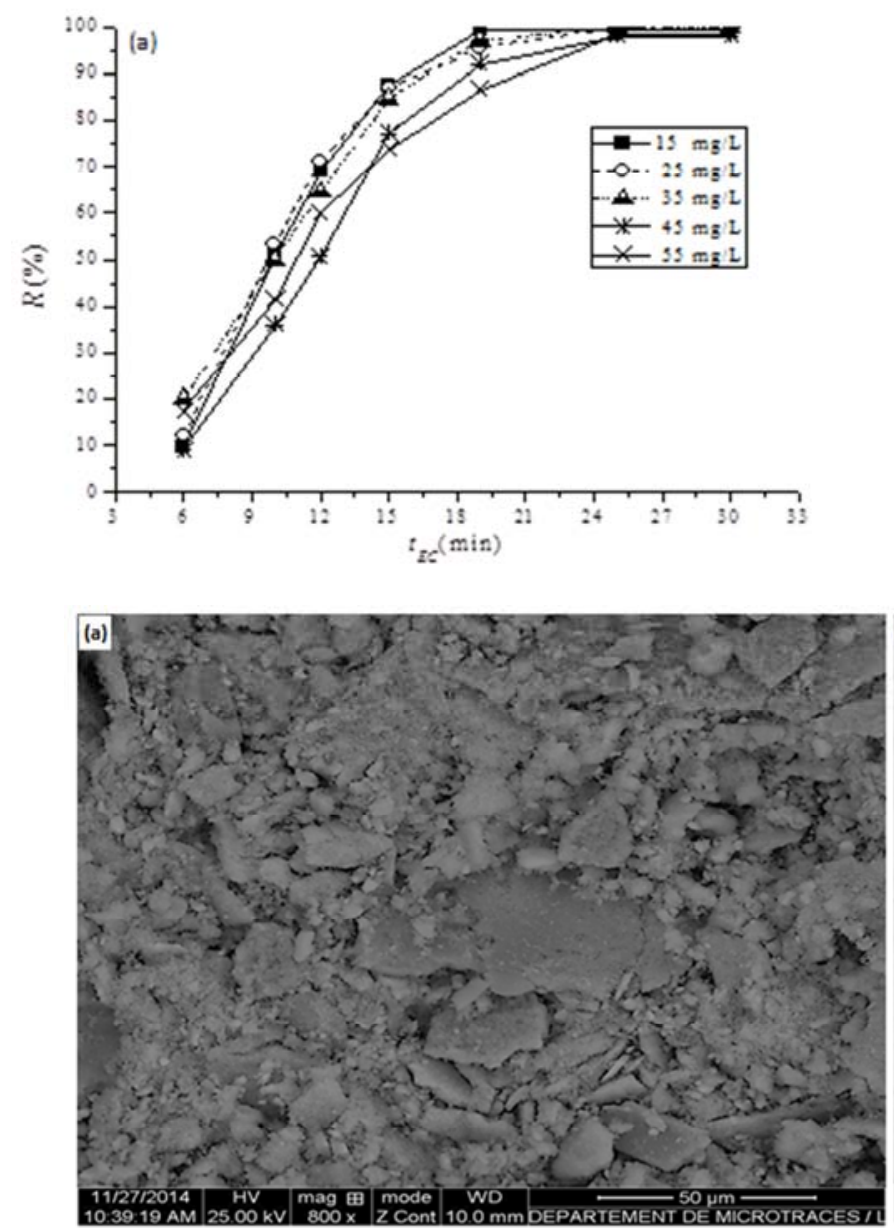

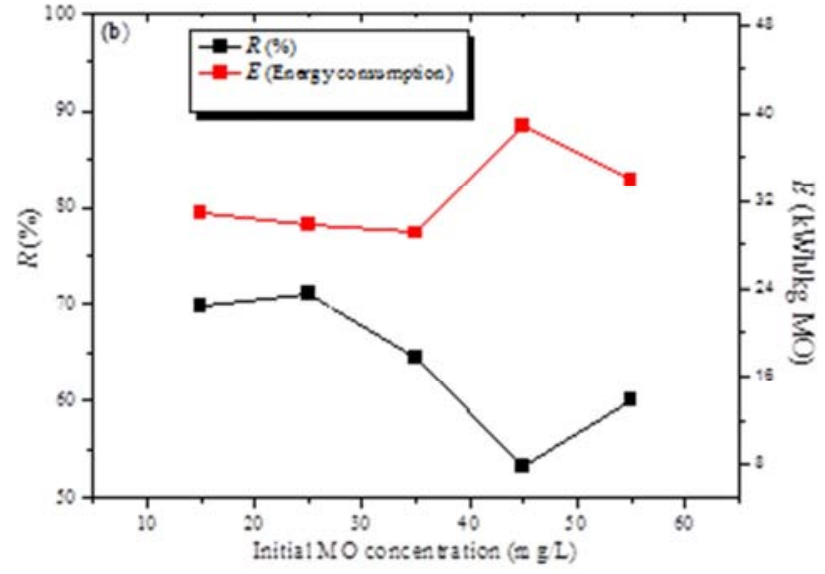

Figure 9. (a) Effect of $C_{M O}$ on $R(\%)$. (b) Effect of $C_{M O}$ on $R(\%)$ and $E\left(C_{\mathrm{NaCl}}=\right.$ $\left.1.6 \mathrm{~g} / \mathrm{L}, J=64 \mathrm{~A} / \mathrm{m}^{2}, d=2 \mathrm{~cm}, \mathrm{pH}=7.25, \mathrm{SV}=270 \mathrm{rpm}, t_{E C}=12 \mathrm{~min}\right)$.

Based on the obtained results of the EC treatment, $R(\%)$ decreases as the concentration of MO augments. After $12 \mathrm{~min}$ of EC treatment, decolorization efficiencies of $71.11 \%$ and $60 \%$ are observed for the initial concentrations 25 and $55 \mathrm{mg} / \mathrm{L}$; these rates increase gradually to $86.89 \%$ and $73.81 \%$ for a duration of $15 \mathrm{~min}$, respectively (Figure 9(a)). The energies consumed during the EC treatment of $\mathrm{MO}$ increase up to 31 and $33 \mathrm{kWh} / \mathrm{kg}$, respectively (Figure $9(\mathrm{~b})$ ).

\subsection{Flocs Characterization}

The precipitates formed during the EC treatment were subjected to SEM visualization to observe the surface condition of the different kinds of generated textures. Figure 10 presents SEM images of the flocs generated by EC process at the optimum conditions.

Figure 10. SEM of the flocs generated by EC process at the optimum conditions $\left(C_{M O}=15 \mathrm{mg} / \mathrm{L}, C_{\mathrm{NaCl}}=1.6 \mathrm{~g} / \mathrm{L}, \mathrm{J}=64 \mathrm{~A} / \mathrm{m}^{2}, d=2 \mathrm{~cm}, t_{E C}=30 \mathrm{~min}, \mathrm{pH}=7.25\right.$, $S V=270 \mathrm{rpm})$.

The SEM observations show that the flocs formed by the treatment of the EC have two distinct morphologies: a lumpy structure and an amorphous structure, formed by particles of various sizes (Figure 10(a) and (b)). Small particles promote the condensation of flocs and thus the increase of the surface of the colloids.
Figure 11 presents the EDX of the flocs generated by EC process at the optimum conditions. Table 2 lists the quantitative composition for atomic $(A t)$ and weight $(W t)$ percentage of the elements present in the floc generated by EC. 


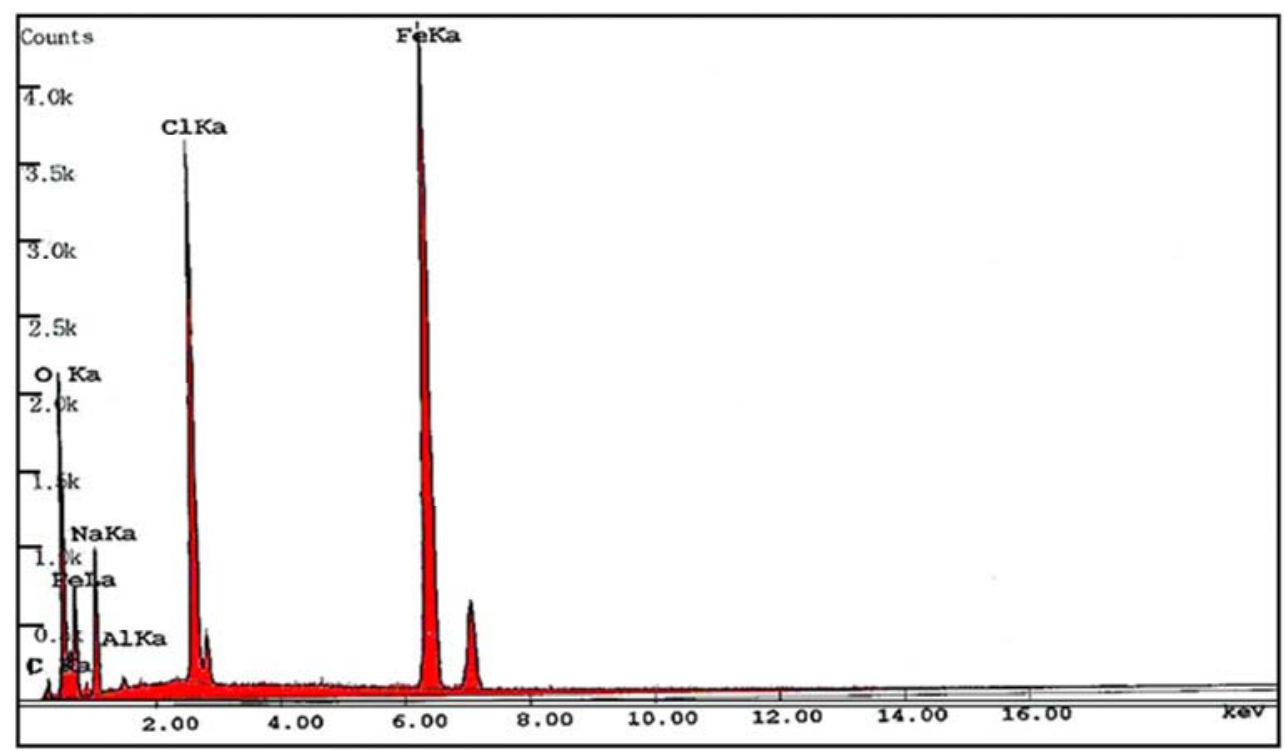

Figure 11. EDX of the flocs generated by EC process at the optimum conditions $\left(C_{M O}=15 \mathrm{mg} / \mathrm{L}, C_{\mathrm{NaCl}}=1.6 \mathrm{~g} / \mathrm{L}, \mathrm{J}=64 \mathrm{~A} / \mathrm{m}^{2}, d=2 \mathrm{~cm}, t_{E C}=30 \mathrm{~min}, \mathrm{pH}=7.25\right.$, $S V=270 \mathrm{rpm})$.

Table 2. Quantitative composition for atomic (At) and weight (Wt) percentage of the elements present in the floc generated by EC.

\begin{tabular}{lllllll}
\hline Elements & Fe & O & Cl & Na & C & Al \\
\hline$W t(\%)$ & 45.12 & 28.33 & 12.54 & 8.90 & 4.71 & 0.40 \\
At $(\%)$ & 21.68 & 47.52 & 9.49 & 10.38 & 10.52 & 0.40 \\
\hline
\end{tabular}

The EDX analysis of the surface of the flocs formed after the treatment with EC shows a spectrum (Figure 11) with levels of major elements of iron, oxygen and chloride, as well as carbon, sodium and aluminium are detected as minor elements (Table 2). Similar results are obtained by Garg and Prasad [63].

\subsection{Absorbance Tracking}

Figure 12 presents the evolution of the absorbance of $\mathrm{MO}$ and degradation products as a function of $t_{E C}\left(C_{M O}=15 \mathrm{mg} / \mathrm{L}\right.$, $\left.C_{\mathrm{NaCl}}=1.6 \mathrm{~g} / \mathrm{L}, J=64 \mathrm{~A} / \mathrm{m}^{2}, d=2 \mathrm{~cm}, \mathrm{pH}=7.25\right)$ and Figure 12 presents the mechanism of the degradation of MO.

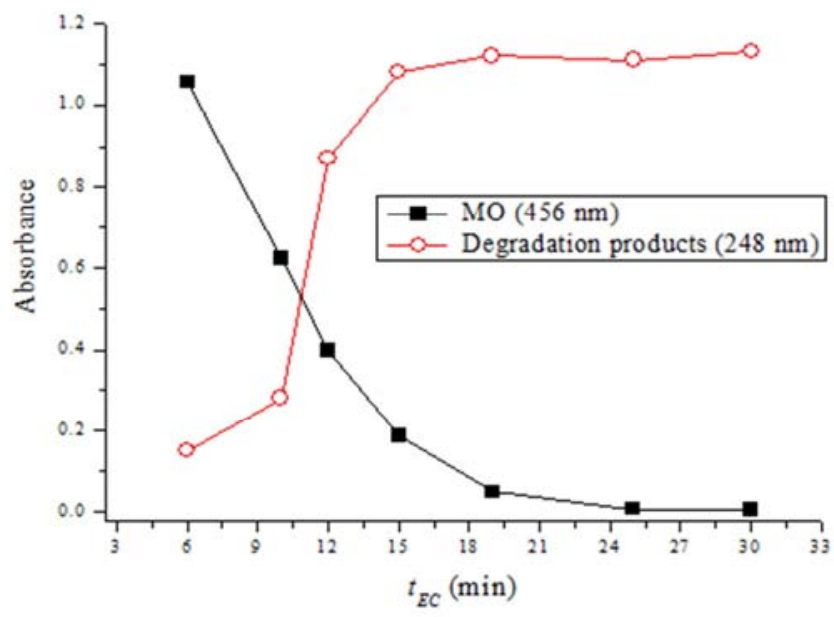

Figure 12. Evolution of the absorbance of $M O$ and degradation products as a function of $t_{E C}\left(C_{M O}=15 \mathrm{mg} / \mathrm{L}, C_{\mathrm{NaCl}}=1.6 \mathrm{~g} / \mathrm{L}, J=64 \mathrm{~A} / \mathrm{m}^{2}, d=2 \mathrm{~cm}, \mathrm{pH}=\right.$ 7.25).

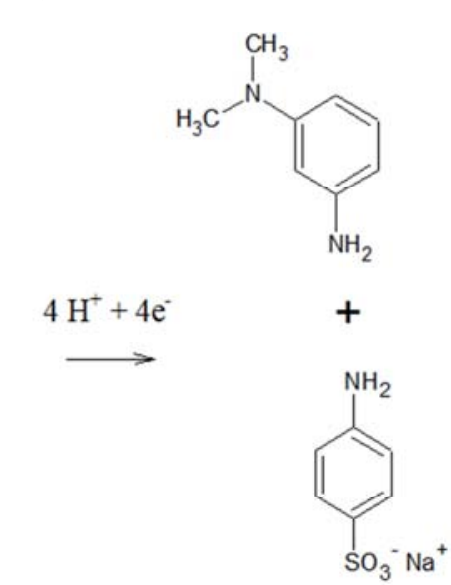

Sulfuric Acid

Figure 13. Mechanism of the degradation of $M O\left(C_{M O}=15 \mathrm{mg} / \mathrm{L}, C_{\mathrm{NaCl}}=1.6 \mathrm{~g} / \mathrm{L}, \mathrm{J}=64 \mathrm{~A} / \mathrm{m}^{2}, d=2 \mathrm{~cm}, t_{E C}=30 \mathrm{~min}, \mathrm{pH}=7.25, \mathrm{SV}=270 \mathrm{rpm}\right)$. 
The monitoring of the evolution of the MO reduction has been carried out particularly in the visible range but it can be usefully observed the by-products in the ultraviolet domain. As shown in Figure 13, the shape of the curve illustrates that the absorbance of the $\mathrm{MO}$ at $465 \mathrm{~nm}$ decreases until 0.39 . Following the evolution of the by-product absorbance $(\mathrm{N}$, $\mathrm{N}$-dimethylaniline) at $248 \mathrm{~nm}$ during the treatment of $\mathrm{MO}$, the absorbance increases progressively from 6 to $10 \mathrm{~min}$ to reach a value 0.21 for the EC after $10 \mathrm{~min}$ and stabilizes after $12 \mathrm{~min}$. This stabilization of the absorbance corresponds to the accumulation of degradation by-products (Figure 13).

\section{Conclusions}

The main important points drawn from this review may be listed as:

The study highlighted the influence of the nature of SE and its concentration. Indeed, $\mathrm{NaCl}$ seems to be the most advantageous because chloride ions can significantly reduce the adverse effects of other anions. The favorable concentration is $1.6 \mathrm{~g} / \mathrm{L}$, beyond which any increase leads to a decrease in efficiency. The intensity of the current appears as a determining factor. Indeed, the increase of $J$ is favorable for the EC process. The judicious choice of the initial conditions $\left(t_{E C}\right.$ and $J$ ) will make it possible to limit the excessive release of the hydrogen. The efficiency of the EC process is also favored over a wide range of initial $\mathrm{pH}$ ranging from 3 to 8 . The treatment of the synthetic solution is preferably carried out at $\mathrm{pH} 7.25$. The kinetics of discoloration is affected by the distance between the two electrodes. Indeed, it is found that during the treatment that the rate during the treatment with the EC reaches $83 \%$ with $J=64 \mathrm{~A} / \mathrm{m}^{2}$. EC process is once again confirmed as interesting and valuable technology in the perspective of industrial scale implementations.

\section{Acknowledgement}

This study was supported by the Saudi Ministry of Education under the framework of the National Initiative on Creativity and Innovation Project (2440-81441-2017) in Saudi Universities. The authors gratefully acknowledge the support of their research program.

\section{Abbreviations}

$\begin{array}{ll}\mathrm{C}_{\mathrm{NaCl}} & \text { NaCl concentration }(\mathrm{g} / \mathrm{L}) \\ \mathrm{C}_{\mathrm{SE}} & \mathrm{SE} \text { concentration }(\mathrm{g} / \mathrm{L}) \\ \mathrm{C}_{\mathrm{MO}} & \text { MO concentration }(\mathrm{mg} / \mathrm{L}) \\ \mathrm{d} & \text { Inter-electrode distance }(\mathrm{cm}) \\ \mathrm{E} & \text { Energy consumption }(\mathrm{kWh} / \mathrm{kg} \text { of } \mathrm{MO}) \\ \mathrm{EC} & \text { Electrocoagulation } \\ \mathrm{EDX} & \text { Energy disperses X-ray } \\ \mathrm{J} & \text { Current density }\left(\mathrm{A} / \mathrm{m}^{2}\right) \\ \mathrm{MO} & \text { Methyl orange } \\ \mathrm{R}(\%) & \text { Removal efficiency } \\ \mathrm{SE} & \text { Supporting electrolyte }\end{array}$

$\begin{array}{ll}\text { SEM } & \text { Scanning electron microscopy } \\ \text { SV } & \text { Stirring velocity (rpm) } \\ t_{\text {EC }} & \text { EC time (min) }\end{array}$

\section{References}

[1] S. Irki, D. Ghernaout, M. W. Naceur, Decolourization of Methyl Orange (MO) by Electrocoagulation (EC) using iron electrodes under a magnetic field (MF), Desalin. Water Treat. 79 (2017) 368-377.

[2] D. Ghernaout, A. I. Al-Ghonamy, N. Ait Messaoudene, M. Aichouni, M. W. Naceur, F. Z. Benchelighem, A. Boucherit, Electrocoagulation of Direct Brown 2 (DB) and BF Cibacete Blue (CB) using aluminum electrodes, Sep. Sci. Technol. 50 (2015) 1413-1420.

[3] C. Fernández, M. S. Larrechi, M. P. Callao, An analytical overview of processes for removing organic dyes from wastewater effluents, Trends Analyt. Chem. 29 (2010) 1202-1211.

[4] M. R. Majdi, I. Danaee, S. Nikmanesh, Kinetic and thermodynamic investigations on the electrocoagulation of methyl orange from aqueous solution using aluminum electrodes, Bulgarian Chem. Commun. 48 (2016) 628-635.

[5] S. A. Popli, U. D. Patel, Electrochemical decolourization of Reactive Black 5 in an undivided cell using Ti and graphite anodes: Effect of polypyrrole coating on anodes, J. Electrochem. Sci. Eng. 5 (2015) 145-156.

[6] N. Kannan, G. Karthikeyan, N. Tamilselvan, Comparison of treatment potential of electrocoagulation of distillery effluent with and without activated Areca catechu nut carbon, J. Hazard. Mater. B137 (2006) 1803-1809.

[7] [7] D. Ghernaout, Environmental principles in the Holy Koran and the Sayings of the Prophet Muhammad, Am. J. Environ. Prot. 6 (2017) 75-79.

[8] D. Ghernaout, B. Ghernaout, A. Kellil, Natural organic matter removal and enhanced coagulation as a link between coagulation and electrocoagulation, Desalin. Water Treat. 2 (2009) 209-228.

[9] D. Ghernaout, B. Ghernaout, A. Boucherit, M. W. Naceur, A. Khelifa, A. Kellil, Study on mechanism of electrocoagulation with iron electrodes in idealised conditions and electrocoagulation of humic acids solution in batch using aluminium electrodes, Desalin. Water Treat. 8 (2009) 91-99.

[10] D. Ghernaout, A. I. Al-Ghonamy, M. W. Naceur, A. Boucherit, N. A. Messaoudene, M. Aichouni, A. A. Mahjoubi, N. A. Elboughdiri, Controlling coagulation process: From Zeta potential to streaming potential, Am. J. Environ. Prot. 4 (2015) 16-27.

[11] D. Ghernaout, A. I. Al-Ghonamy, A. Boucherit, B. Ghernaout, M. W. Naceur, N. Ait Messaoudene, M. Aichouni, A. A. Mahjoubi, N. A. Elboughdiri, Brownian motion and coagulation process, Am. J. Environ. Prot. 4 (2015) 1-15.

[12] D. Ghernaout, A. Simoussa, A. Alghamdi, B. Ghernaout, N. Elboughdiri, A. Mahjoubi, M. Aichouni, A. E. A. El-Wakil, Combining lime softening with alum coagulation for hard Ghrib dam water conventional treatment, Intern. J. Adv. Appl. Sci. 5 (2018) 61-70. 
[13] D. Ghernaout, Entropy in the Brownian motion (BM) and coagulation background, Colloid Surface Sci. 2(4) (2017) 143-161.

[14] D. Ghernaout, A. Badis, G. Braikia, N. Matâam, M. Fekhar, B. Ghernaout, A. Boucherit, Enhanced coagulation for algae removal in a typical Algeria water treatment plant, Environ. Eng. Manag. J. 16 (2017) 2303-2315.

[15] A. Boucherit, S. Moulay, D. Ghernaout, A. I. Al-Ghonamy, B. Ghernaout, M. W. Naceur, N. Ait Messaoudene, M. Aichouni, A. A. Mahjoubi, N. A. Elboughdiri, New trends in disinfection by-products formation upon water treatment, J. Res. Develop. Chem., 2015, DOI: 10.5171/2015.628833.

[16] D. Ghernaout, A. Boucherit, Review of coagulation's rapid mixing for NOM removal, J. Res. Develop. Chem., 2015, DOI: $10.5171 / 2015.926518$.

[17] B. Ghernaout, D. Ghernaout, A. Saiba, Algae and cyanotoxins removal by coagulation/flocculation: A review, Desalin. Water Treat. 20 (2010) 133-143.

[18] D. Ghernaout, S. Moulay, N. Ait Messaoudene, M. Aichouni, M. W. Naceur, A. Boucherit, Coagulation and chlorination of NOM and algae in water treatment: A review, Intern. J. Environ. Monit. Analy. 2 (2014) 23-34.

[19] D. Ghernaout, The hydrophilic/hydrophobic ratio vs. dissolved organics removal by coagulation - A review, J. King Saud Univ. - Sci. 26 (2014) 169-180.

[20] D. Ghernaout, Advanced oxidation phenomena in electrocoagulation process: A myth or a reality?, Desalin. Water Treat. 51 (2013) 7536-7554.

[21] A. Ghalwa, M. Nasser, N. B. Farhat, Removal of abamectin pesticide by electrocoagulation process using stainless steel and iron electrodes, J. Environ. Anal. Chem. 2 (2015): 134. doi:10.4172jreac.1000134.

[22] D. Ghernaout, C. Benblidia, F. Khemici, Microalgae removal from Ghrib Dam (Ain Defla, Algeria) water by electroflotation using stainless steel electrodes, Desalin. Water Treat. 54 (2015) 3328-3337.

[23] D. Ghernaout, A. I. Al-Ghonamy, S. Irki, A. Grini, M. W. Naceur, N. Ait Messaoudene, M. Aichouni, Decolourization of bromophenol blue by electrocoagulation process, Trends Chem. Eng. 15 (2014) 29-39.

[24] D. Ghernaout, A. I. Al-Ghonamy, M. W. Naceur, N. Ait Messaoudene, M. Aichouni, Influence of operating parameters on electrocoagulation of C. I. disperse yellow 3, J. Electrochem. Sci. Eng. 4 (2014) 271-283.

[25] P. Manikandan, P. N. Palanisamy, R. Baskar, P. Sakthisharmila, P. Sivakumar, A comparative study on the competitiveness of photo-assisted chemical oxidation (PACO) with electrocoagulation (EC) for the effective decolorization of reactive blue dye, Iran. J. Chem. Chem. Eng. Vol. 36 (2017) 71-85.

[26] D. Ghernaout, M. W. Naceur, B. Ghernaout, A review of electrocoagulation as a promising coagulation process for improved organic and inorganic matters removal by electrophoresis and electroflotation, Desalin. Water Treat. 28 (2011) 287-320.

[27] W.-L. Chou, C.-T. Wang, C.-W. Hsu, K.-Y. Huang, T.-C. Liu, Removal of total organic carbon from aqueous solution containing polyvinyl alcohol by electrocoagulation technology,
Desalination 259 (2010) 103-110.

[28] I. Linares-Hernández, C. Barrera-Díaz, G. Roa-Morales, B. Bilyeu, F. Ureña-Núñez, A combined electrocoagulationsorption process applied to mixed industrial wastewater, J. Hazard. Mater. 144 (2007) 240-248.

[29] D. Ghernaout, A. Badis, B. Ghernaout, A. Kellil, Application of electrocoagulation in Escherichia Coli culture and two surface waters, Desalination 219 (2008) 118-125.

[30] D. Ghernaout, B. Ghernaout, A. Saiba, A. Boucherit, A. Kellil, Removal of humic acids by continuous electromagnetic treatment followed by electrocoagulation in batch using aluminium electrodes, Desalination 239 (2009) 295-308.

[31] A. Saiba, S. Kourdali, B. Ghernaout, D. Ghernaout, In Desalination, from 1987 to 2009, the birth of a new seawater pretreatment process: Electrocoagulation-an overview, Desalin. Water Treat. 16 (2010) 201-217.

[32] D. Ghernaout, The Holy Koran Revelation: Iron is a "sent down" metal, Am. J. Environ. Prot. 6 (2017) 101-104.

[33] D. Ghernaout, B. Ghernaout, M. W. Naceur, Embodying the chemical water treatment in the green chemistry - A review, Desalination 271 (2011) 1-10.

[34] D. Ghernaout, The best available technology of water/wastewater treatment and seawater desalination: Simulation of the open sky seawater distillation, Green Sustain. Chem. 3 (2013) 68-88.

[35] D. Ghernaout, Electrocoagulation process: Achievements and green perspectives, Colloid Surface Sci. 3 (2018) 1-5.

[36] D. Ghernaout, S. Irki, A. Boucherit, Removal of $\mathrm{Cu}^{2+}$ and $\mathrm{Cd}^{2+}$, and humic acid and phenol by electrocoagulation using iron electrodes, Desalin. Water Treat. 52 (2014) 3256-3270.

[37] D. Ghernaout, B. Ghernaout, A. Boucherit, Effect of $\mathrm{pH}$ on electrocoagulation of bentonite suspensions in batch using iron electrodes, J. Disper. Sci. Technol. 29 (2008) 1272-1275.

[38] D. Ghernaout, M. W. Naceur, A. Aouabed, On the dependence of chlorine by-products generated species formation of the electrode material and applied charge during electrochemical water treatment, Desalination 270 (2011) 9-22.

[39] D. Ghernaout, A. Mariche, B. Ghernaout, A. Kellil, Electromagnetic treatment-bi-electrocoagulation of humic acid in continuous mode using response surface method for its optimization and application on two surface waters, Desalin. Water Treat. 22 (2010) 311-329.

[40] N. K. Shammas, Coagulation and flocculation, in: L. K. Wang, Y.-T. Hung, N. K. Shammas (Eds.), Handbook of Environmental Engineering, Physicochemical Treatment Processes, vol. 3, The Humana Press, Totowa, NJ, 2005 (Chapter 4), 103-139.

[41] D. Ghernaout, B. Ghernaout, From chemical disinfection to electrodisinfection: The obligatory itinerary?, Desalin. Water Treat. 16 (2010) 156-175.

[42] Y. Zhang, Y. Cong, Q. Wang, Electrocoagulation- $\mathrm{TiO}_{2}$ photo-assisted combined system applied to methyl orange wastewater removal, Environ. Eng. Manag. J. 12 (2013) 517-526.

[43] K.-W. Pi, Q. Xiao, H.-Q. Zhang, M. Xia, A. R. Gerson, Decolorization of synthetic Methyl Orange wastewater by electrocoagulation with periodic reversal of electrodes and optimization by RSM, Process Safety Environ. Protect. 92 (2014) 796-806. 
[44] C. J. Izquierdo, P. Canizares, M. A. Rodrigo, J. P. Leclerc, G. Valentin, F. Lapicque, Effect of the nature of the supporting electrolyte on the treatment of soluble oils by electrocoagulation, Desalination, 255 (2010) 15-20.

[45] A. de Mello Ferreira, M. Marchesiello, P.-X. Thivel, Removal of copper, zinc and nickel present in natural water containing $\mathrm{Ca}^{2+}$ and $\mathrm{HCO}_{3}{ }^{-}$ions by electrocoagulation, Sep. Purif. Technol. 107 (2013) 109-117.

[46] D. Ghernaout, B. Ghernaout, On the controversial effect of sodium sulphate as supporting electrolyte on electrocoagulation process: A review, Desalin. Water Treat. 27 (2011) 243-254.

[47] N. Daneshvar, A. Oladegaragoze, N. Djafarzadeh, Decolorization of basic dye solutions by electrocoagulation: An investigation of the effect of operational parameters, J. Hazard. Mater. B129 (2006) 116-122.

[48] M. Kobya, E. Demirbas, O. T. Can, M. Bayramoglu, Treatment of levafix orange textile dye solution by electrocoagulation, J. Hazard. Mater. 132 (2006) 183-188.

[49] M. Y. A. Mollah, J. A. G. Gomes, K. K. Das, D. L. Cocke, Electrochemical treatment of Orange II dye solution-Use of aluminum sacrificial electrodes and floc characterization, J. Hazard. Mater. 174 (2010) 851-858.

[50] S. Bayar, Y. Ş. Yıldız, A. E. Yılmaz, Ş. İrdemez, The effect of stirring speed and current density on removal efficiency of poultry slaughterhouse wastewater by electrocoagulation method, Desalination 280 (2010) 103-107.

[51] D. Ghernaout, B. Ghernaout, Sweep flocculation as a second form of charge neutralisation - A review, Desalin. Water Treat. 44 (2012) 15-28.

[52] D. Ghernaout, B. Ghernaout, On the concept of the future drinking water treatment plant: Algae harvesting from the algal biomass for biodiesel production-A Review, Desalin. Water Treat. 49 (2012) 1-18.

[53] S. Cotillas, J. Llanos, P. Cañizares, S. Mateo, M. A. Rodrigo, Optimization of an integrated electrodisinfection/electrocoagulation process with Al bipolar electrodes for urban wastewater reclamation, Water Res. 47 (2013) 1741-1750.
[54] M. I. Kerwick, S. M. Reddy, A. H. L. Chamberlain, D. M. Holt, Electrochemical disinfection, an environmentally acceptable method of drinking water disinfection?, Electrochim. Acta 50 (2005) 5270-5277.

[55] B. Al Aji, Y. Yavuz, A. S. Koparal, Electrocoagulation of heavy metals containing model wastewater using monopolar iron electrodes, Sep. Purif. Technol. 86 (2012) 248-254.

[56] M. Muthukumar, M. Thalamadai Karuppiah, G. Bhaskar Raju, Electrochemical removal of CI Acid orange 10 from aqueous solutions, Sep. Purif. Technol. 55 (2007) 198-205.

[57] C. Phalakornkule, S. Polgumhang, W. Tongdaung, B. Karakat, T. Nuyut, Electrocoagulation of blue reactive, red disperse and mixed dyes, and application in treating textile effluent, Environ. Manage. 91 (2010) 918-926.

[58] D. Belhout, D. Ghernaout, S. Djezzar-Douakh, A. Kellil, Electrocoagulation of Ghrib dam's water (Algeria) in batch using iron electrodes, Desalin. Water Treat. 16 (2010) 1-9.

[59] D. Ghernaout, M. W. Naceur, Ferrate(VI): In situ generation and water treatment - A review, Desalin. Water Treat. 30 (2011) 319-332.

[60] S. Zodi, B. Merzouk, O. Potier, F. Lapicque, J.-P. Leclerc, Direct red 81 dye removal by a continuous flow electrocoagulation/flotation reactor, Sep. Purif. Technol. 108 (2013) 215-222.

[61] N. Mameri, A. R. Yeddou, H. Lounici, D. Belhocine, H. Grib, B. Bariou, Defluoridation of Septentrional Sahara water of North Africa by electrocoagulation process using bipolar aluminium electrodes, Water Res. 32 (1998) 1604-1612.

[62] N. Daneshvar, H. Ashassi Sorkhabi, M. B. Kasiri, Decolorization of dye solution containing Acid Red 14 by electrocoagulation with a comparative investigation of different electrode connections, J. Hazard. Mater. B112 (2004) 55-62.

[63] K. K. Garg, B. Prasad, Development of Box Behnken design for treatment of terephthalic acid wastewater by electrocoagulation process: Optimization of process and analysis of sludge, J. Environ. Chem. Eng. 4 (2016) 178-190. 